\title{
Investigation the Physical and Rheological Properties of Bitumen Modified with Warm Mix Asphalt Additive
}

\author{
İslam GÖKALP $1^{*}(\mathbb{D})$ \\ ${ }^{1 *}$ Batman University, Faculty of Engineering and Architecture, Civil Enginnering, . (e-mail: islamgokalp@gmail.com).
}

\section{ARTICLE INFO}

Received: Jul., 08. 2021

Revised: Sep., 13. 2021

Accepted: Sep., 15. 2021

\section{Keywords:}

Bitumen

Modification

Polymer

Sasobit

Warm Mix Asphalt

Corresponding author: İslam GÖKALP

ISSN: 2536-5010 | e-ISSN: 2536-5134

DOI: https://doi.org/10.36222/ejt.966398

\section{ABSTRACT}

Bituminous binders constitute $4-7 \%$ of the flexible pavements by weight play an important role on the structural and functional performance of pavements. Traditional hot mix asphalt (HMA) production is done at $150-190{ }^{\circ} \mathrm{C}$ that results high-energy usage, smoke and odor emission therefore significant cost loss and environmental damage. Increasing environmental awareness has questioned whether HMA can be produced at lower temperatures. Consequently, warm mix asphalt (WMA) and cold asphalt applications were developed as alternatives. WMA applications researched within the scope the current study can be done by using organic, chemical additives or foaming methods, which are based on the reduction of the viscosity of bitumen. The aim of this study was to modify the base bitumen by adding WMA additive called Sasobit, the most widely used chemical product in the world, within the rates between $1 \%$ and $5 \%$ and therefore to investigate the changes in physical and rheological properties of bitumen. In this research, penetration, softening and flash point, viscosity tests were applied under physical properties, thermal sensitivity was analysed, and rheological properties of base and short-term aging from, which required hightemperature grade of bitumen, were investigated using dynamic shear rheometer. Eventually, the effect of using Sasobit in modification were determined. A brief evaluation in the light of present studies were done on economic and environmental effect of using WMA technology. The results showed that significant changes occur in the studied properties of bitumen except of flash point.

\section{INTRODUCTION}

Bituminous binders are adhesive and water-resistant construction materials with volatile components. As a valuable and versatile product, bitumen can be obtained from crude oil with a series of industrial processes as well as from lake and rock-induced formation, naturally. There are numerous usage area of bitumen for different purposes including adhesive, infiltration, pie protector, water impermeable additive, pavement binder etc. Moreover, bitumen are visco-elastic, sensitive to heat material, and dissoluble by $99 \%$ within toluene based chemicals [1]. Although they have complex chemical components, four main component take significant role in the form of bitumen. These are (1) Saturated, (2) Asphaltene, (3) Resin, and (4) Aromatics [2, 3]. Due to their origin and production process, there are significant differences between their atomic structure, size and weight of molecular structure, and aromatic properties etc., which cause significant changes in physical and rheological properties [4-12].

Flexible pavement consists of large part (approximately 90$97 \%$ ) of network of highway in our country, Turkey such as the other country including Germany, Australia, Unite States of America, and New Zealand [13]. Flexible pavement consists of aggregate and bitumen beside of some additives. Aggregate forms $93-96 \%$ by weight of the pavement and the remaining part by bitumen and additive. The role of the aggregate is to provide a skeleton of pavement, while that of bitumen is to keep the aggregates together and prevent them to disintegrate under repeated traffic loads and harsh environmental conditions [1417]. Although the rate of bitumen is quite lower than that of aggregates, it is important to provide superior functional and structural performance from constructed pavement.

Under increasing traffic loads and changeable climatic conditions, the expected performance from traditional bituminous binders cannot be provided, generally. For this reason, it is necessary to improve the bitumen characteristics to resist against such harsh conditions. This directs the researchers interests in modification of bitumen with different additive that may be chemical product for sale and/or industrial or household waste. The materials used to modifiye bitumen changes bitumen characteristics including physical and rheological properties, and chemical structure [17, 18]. All has significant effect on functional and structural performance of pavements. Beside of durability concerns, constructing economic and ecofriendly pavement construction are crucial for sustainability. In this respect, significant number of studies focused on the bitumen modification [19-24]. 
Bitumen is a sensitive material against temperature. The physical form of them is viscous as exposed to high temperature, while in the form of solid or semi-solid at low temperature conditions. According to hot mix asphalt (HMA) production processes, flexible pavement is constructed in ideal temperature ranges between 120 and $190{ }^{\circ} \mathrm{C}$. To provide an efficient mixing process for HMA, standards identify certain limitations for viscosity values, and the HMA is prepared according to the requirements given to the contractor [25]. In this case, significant amount of energy are required to produce HMA at desired conditions, which causes of high costs and adverse effects on environment due to emission and odor [26]. Environmental and economic awareness direct the to whom it may concern to use the present energy resources, efficiently [27-29]. This encourage the researchers to improve innovative technological developments to provide ecologic, energyefficient and labor friendly production. In this regard, numerous investigations have been done to make the bitumen structural and functional properties better and/or stable under high traffic loads and harsh environmental conditions. Novel additives and technological processes have been developed being used in bitumen modification and to production of HMA. Throughout the development process, new method in production of asphalt mixture including cold and warm mix asphalt (WMA) have been developed [30, 31]. The recent studies show that the temperatures for mixing and compaction can be reduced about $15{ }^{\circ} \mathrm{C}$, which leads to significant reduction in the cost of investment and emerged amount of emission and odor that are hazardous for living creatures health [32]. Such advantages are the reasons that encourage the researcher and contractor to construct flexible pavements with WMA technology. There are numerous WMA additives including organic additives, chemical additives, and the technic consists of water injections and /or foamed with minerals [33]. Sasobit is one of common WMA polymer that used as an additive in the scope of this study.

Numerous researcher have investigated the effect of WMA additives on bitumen properties and/or performance of HMA produced with them. There are some of them at the following presented in brief.

Arshad et all. [34] modified the bitumen with Sasobit in certain rate ranging between 1 and $3 \%$ with 0.5 increments. The authors investigate the effect of WMA on bitumen samples with penetration and viscosity at different temperature ranging between 70 and $135^{\circ} \mathrm{C}$. They reported that the penetration and viscosity values above $115^{\circ} \mathrm{C}$ are lower than the one found for base bitumen. Moreover, they indicated that the viscosity of WMA samples higher at 70 and $80^{\circ} \mathrm{C}$. Fazaeli et all. [35] used different WMA additive called Fischer Tropsch- Paraffin in certain rates from 1 to $4 \%$ for modification of bitumen with 5822 graded according to SuperPAVE performance grade (PG) system. To investigate the changes in properties of bitumen, physical and rheological tests were performed on the WMA samples. The results reported by authors were that significant changes occur in both physical and rheological properties. For examples, the PG of WMA sample with $4 \%$ additive was determined as 70-22. However, the changes in properties at intermediate temperatures were not significant. Moreover, the test performed with rotational viscometer showed that there is increase in WMA additive rate causes decreasing in mixing and compaction temperatures about $15-25^{\circ} \mathrm{C}$. Yero and Hainin [36] reported that significant increasing in temperature susceptibility of WMA samples produced with 1 and 5\% additive is observed while examined with penetration index (PI) and penetration viscosity number (PVN). The changes in viscosity were evaluated with rotational viscometer under the temperature ranging from 60 and $150{ }^{\circ} \mathrm{C}$. The viscosity was determined higher at low temperature, while lower at higher temperature, especially the one bigger than $100{ }^{\circ} \mathrm{C}$ while compared with base one. Similar to the summarized studies, higher rutting resistance in WMA samples was determined. Cao and Ji [37] investigated long-term performance of Sasobit modified bitumen produced in certain rates from 2 to $5 \%$ by conventional and rheological test methods. The reported results showed that significant changes occur in properties of produced WMA samples and the level of changes are depended on bitumen and additive type as well as additive rates. Dokandari and Topal [38] investigated the short and long-term aged properties of WMA produced with foamed and nonfoamed additive up to $7 \%$ by weight of bitumen in rate. Conventional bitumen tests and the indirect tension tests were performed on WMA samples. Besides, temperature susceptibility of WMA was examine with PI analysis. The results implied by authors that the studied WMA produced with non-foamed exhibits better properties than that of produced with foamed additive. The influence of water on warmmodified asphalt in the views of adhesion, morphology and chemical characteristics were investigated in a study done by Liu et all. [39]. Highlighted results were that Sasobit can reduce the water-induced adhesion degradation and water-induced aging and Sasobit can delay polar enrichment of asphalt. Yue et all [40] investigated the fatigue characteristics and healing potential of asphalt binder modified with Sasobit and polymers under linear amplitude sweep test. They indicated that after Sasobit modification, the performance of polymer modified bitumen by means of fatigue life, healing capacities. Bhat and Mir [41] investigated the performance of Nano-modified asphalt binders incorporated with warm mix additives such as Fisher-Tropsch wax (FT wax) and organosilane. The results of this study revealed that incorporation of WMA additives decreased the viscosity of both the control and nanosilicamodified asphalt binders, while improved elevated temperature performance and the resistance against fatigue cracking and aging.

As can be seen from summarized studies, WMA addition are considerably effective on bitumen and asphalt concrete properties. This task is not new for the world, but it is quite new with a few of study for our country, Turkey. To fill the gap in the literature of the country and to support and improve the existing worldwide studies, the current study is established. Moreover, the level of effect may change due to both additive and bitumen type and origin, therefore to evaluate it for our country condition; it is valuable to analyze the characteristics of bitumen produced in Turkey modified with Sasobit. To achieve the aim, Sasobit was used in modification to produce WMA in different rates from 1 to $5 \%$ by weight of bitumen. Conventional or physical including penetration, softening point, viscosity and flashing point and DSR as well-known rheological test were implemented on WMA samples to determine the effect of Sasobit to bitumen properties. Additional analyses including for thermal susceptibility of bitumen considering Penetration index (PI), Penetration 
Viscosity Number (PVN) methods, and mixing and compaction temperatures considering rotational viscometer test results were done. Consequently, all the test and analyses results were reported and discussed throughout the scope of the current study.

\section{MATERIALS AND METHOD}

\subsection{Materials}

A base bitumen with 50/70 penetration grade and WMA additive, Sasobit, were used. Bitumen was supplied from General Directorate of Highway, $5^{\text {th }}$ Regional Directorate located in Mersin, while Sasobit additive from a commercial firm. The properties of bitumen and Sasobit are given in Table 1 and Table 2, respectively. The codes of the bitumen samples and modification components are shown in Table 3.

TABLE I

PROPERTIES OF BITUMEN

\begin{tabular}{llll}
\hline \hline Property & Standard & Unit & Result \\
\hline Penetration & TS EN 1426 & $0.1 \mathrm{~mm}$ & 66.9 \\
Softening Point & TS EN 1427 & ${ }^{\circ} \mathrm{C}$ & 46.0 \\
Flashing Point & TS EN ISO 2592 & ${ }^{\circ} \mathrm{C}$ & 268.0 \\
Ductility $\left(25^{\circ} \mathrm{C}\right)$ & TS EN 13398-A1 & $\mathrm{cm}$ & 93.0 \\
Viscosity $\left(110^{\circ} \mathrm{C}\right)$ & & & 2263.0 \\
Viscosity $\left(135^{\circ} \mathrm{C}\right)$ & ASTM 4402 & $\mathrm{cP}$ & 517.5 \\
Viscosity $\left(165^{\circ} \mathrm{C}\right)$ & & & 139.2 \\
Penetration Index & TS EN 1427 & - & -1.59 \\
Specific Gravity & TS EN 15326 & $\mathrm{kg} / \mathrm{m} 3$ & 1031.0 \\
SuperPAVE Grading & TS EN 14770 & ${ }^{\circ} \mathrm{C}$ & $70-22$ \\
\hline \hline
\end{tabular}

TABLE 2

PROPERTIES OF SASOBIT

\begin{tabular}{llll}
\hline \hline Property & Standard & Unit & Result \\
\hline Color & - & - & Off-White \\
Odor & - & - & Odorless \\
Flashing Point & TS EN ISO 2592 & ${ }^{\circ} \mathrm{C}$ & 285.0 \\
Specific Gravity & TS EN 15326 & $\mathrm{g} / \mathrm{cm}$ & 0.900 \\
& & 3 & \\
Average Molecular & - & - & $\approx 1000 \mathrm{~g} / \mathrm{mol}$ \\
Mass & & & \\
Ph Value & TS 132 & - & Neutral \\
Physical Form & - & - & Solid \\
Thermal Decomposition & - & ${ }^{\circ} \mathrm{C}$ & 250.0 \\
Temperature & & & \\
Reaction Temperature & TS EN ISO 2207 & ${ }^{\circ} \mathrm{C}$ & $>90$ \\
Water Solubility & - & - & Insoluble \\
\hline \hline
\end{tabular}

TABLE 3

BITUMEN CODES AND MODIFICATION COMPONENTS

\begin{tabular}{ll}
\hline \hline Code & Components \\
\hline BB & Base bitumen \\
SAS- 0.01 & Base bitumen $+1 \%$ (by bitumen weight) Sasobit additive \\
SAS- 0.02 & Base bitumen $+2 \%$ (by bitumen weight) Sasobit additive \\
SAS- 0.03 & Base bitumen $+3 \%$ (by bitumen weight) Sasobit additive \\
SAS- 0.04 & Base bitumen $+4 \%$ (by bitumen weight) Sasobit additive \\
SAS- 0.05 & Base bitumen $+5 \%$ (by bitumen weight) Sasobit additive \\
\hline \hline
\end{tabular}

\subsection{WMA modification procedures}

The modification procedures followed throughout the scope of the study to produce WMA were determined in the light of the earlier studies [42-46]. The steps of the procedures are as following.
(1) The base bitumen was heated at $150 \pm 5{ }^{\circ} \mathrm{C}$ for 60 minutes to make it fluid,

(2) 500 grams of the fluid bitumen was poured in a metal container,

(3) The bitumen-filled container was put on a heater worked at $140 \pm 5{ }^{\circ} \mathrm{C}$ and remained on it for 10 minutes to provide temperature stability,

(4) The Sasobit additive in determined rates were weighted and poured into the heat bitumen,

(5) The Sasobit-bitumen mixture was stirred for 45 minutes under 1500 revolution per minutes (rpm) with a propeller mixer. This process was done for bottom, middle and top section of the bitumen-filled container for 15 minutes, individually to provide homogeneity.

\subsection{Conventional bitumen test methods}

Throughout the scope of study, penetration, softening points, flashing points, rotational viscosity at different temperatures were performed on the WMA samples. The tests were applied at least two times according to the related EN and ASTM standard. Moreover, temperature susceptibility of produced WMA samples were evaluated with penetration index (PI) and penetration-viscosity number (PVN). Mentioned test methods are briefly described at this section.

Penetration test can be applied with a standard needle under certain load and temperatures. The test duration is 5 seconds and thereafter reading the penetration of the needle is taken. In the scope of the current study TS EN 1426 [47] was followed and the applied load was 100 grams, in total.

Softening point test is common test used all over the world to determine the bitumen flow behavior under elevated temperature. The test apparatus are two ring and ball that are in standard size and weight. Besides, a heater with magnet and grade temperature and the fluid with glass container. The principle of the test is based on the temperature values determined after flowing of the samples for a certain distance. Moreover, TS EN 1427 [48] was followed in this study.

Flashing point test is a kind of safety test that enable the operator to determine the flashing and firing point. Since the bitumen is one of construction material with volatile components. If there is not heated the bitumen at temperature in safe range, it may cause explosion due to gas jam or may cause fire while the bitumen contact with a source of fire. Cleveland open cup flash point apparatus was used in this study according to TS ISO EN 2592 [49].

Viscosity test is applied on bitumen to determine the viscous properties of the bitumen under different temperatures. The test is important, since bitumen is one of visco-elastic construction material that the characteristic changes with heating. At low temperature, the bitumen is stiffer while it is more viscous at high temperature. Besides, determining the viscoelastic characteristics of bitumen is essential to identify the temperature for mixing and compaction of asphalt concrete. In this study, Brookfield rorational viscometer method was performed on bitumen samples at different temperatures (110, 135 , and $165^{\circ} \mathrm{C}$ ) according to ASTM 4402 [50]. 
Temperature susceptibility analysis is done to determine the sensitivity of the bitumen to temperature changes. The most common analyzing methods are PI and PVN and these two were taken into consideration to do the analysis in this study.

The following equalities were used to calculate the values refer to the susceptibility of bitumen to temperature.

$$
\begin{aligned}
P I & =\frac{20-500 \times A}{1+50 \times A} \\
A & =\frac{\log (800)-\log P_{25}}{T_{Y N}-25} \\
P V N & =\frac{4,258-0,7967 \times \log P_{25}-\log V}{0,795-0,1858 \log P_{25}}
\end{aligned}
$$

where,

Tsp: Softening point,

$\mathrm{P}_{25}$ : Penetration at $25^{\circ} \mathrm{C}$,

$\mathrm{V}$ : Kinematic viscosity at $135^{\circ} \mathrm{C}$.

\subsection{Rheological bitumen test methods}

The rheological test methods identified in the scope of the SuperPAVE grading system including dynamic shear rheometer, bending beam rheometer and aging methods (rolling thin film oven test and pressure aging vessel) in case of short-term and long-term were used.in assessment of bitumen properties. These test methods were described in brief at the following.

Dynamic shear rheometer test (DSR) is one of the major equipment used in Superior Performing Asphalt Pavements (SuperPAVE) system developed by Strategic Highway Research Program. DSR results gives deep-information about the viscous and/or elastic behavior of bituminous materials under different temperatures either at high or intermediate level and loading conditions [51]. SuperPAVE system requires testing base and aged bitumen samples in case of short-term aging and long-term aging. DSR test can be performed on base and aged bitumen samples within defined logical framework and the results formed throughout specific software program. The test results include complex shear modulus $\left(\mathrm{G}^{*}\right)$ and phase angle $\left(\delta^{\circ}\right)$ of bitumen sample at different temperatures. The available testing temperatures are between 7 and $88^{\circ} \mathrm{C}$, if a logical framework works with water bath system, while the testing temperature range can change while logical frame system integrated with hot/cold air. DSR with a water bath integrated logical frame is used in the scope of the current study.

SuperPAVE system identifies limit values for $\mathrm{G}^{*}$ of base, short-term and long-term ged bitumen samples to evaluate their rutting and fatigue resistance characteristics, which are $1000 \mathrm{~Pa}$ $(1 \mathrm{kPa}), 2200 \mathrm{~Pa}(2.2 \mathrm{kPa})$, and $5 \times 106 \mathrm{~Pa}(5000 \mathrm{kPa})$, respectively. On the other hand, phase angle shows the viscous or elastic form of bitumen samples at each test temperature. If the angle approaches to $0^{\circ}$, it refers to elastic form of bitumen samples, while it approaches to $90^{\circ}$, then it means to viscous from of the samples. By determining $\mathrm{G}^{*}$ and $\delta^{\circ}$, the DSR are able to provide more information about the behavior of asphalt at pavement service temperatures. Some of them are rutting and fatigue resistance of bitumen. Rutting factor is determined with
$\mathrm{G}^{*} / \operatorname{Sin} \delta^{\mathrm{o}}$, while fatigue factor is calculated with $\mathrm{G}^{*} \cdot \operatorname{Sin} \delta^{\mathrm{o}}$. The test was implemented by following TS EN 14770 standard [52].

Aging methods are different for short and long-term cases that are required to determine rutting and fatigue resistance, and to prepare the samples for thermal cracking resistance evaluation. Short-term aging process refers to the aging of bitumen during production to construction of asphalt pavements, while long-term aging process covers the time of pavement construction to the end of pavement service life. It is possible to simulate both aging process of bitumen can be provided in laboratory condition. Rolling thin film oven (RTFO) and pressure aging vessel (PAV) are the most commonly used methods to provide short and long-term aged bitumen samples, respectively. The test temperature is $163{ }^{\circ} \mathrm{C}$ and the time duration is 75 minutes for RTFO method according to the TS EN 12607-1 standard [53]. On the other hand, PAV method can be conducted at different temperature including $90,100,110^{\circ} \mathrm{C}$. In the scope of the study, only shortterm performance of bitumen samples were evaluated and therefore RTFO based experiment conducted on bitumen samples according to related standard.

\section{RESULTS AND DISCUSSION}

The results of the test and analyzing method conducted on bitumen samples are expressed and discussed in this section.

\subsection{Conventional test results}

The results of conventional tests, which are penetration, softening and flashing point, and viscosity with rotational viscometer, applied on bitumen samples are presented in Figure 1. Beside, mixing and compaction temperatures were determined based on the data obtained from viscosity test at 135 and $165^{\circ} \mathrm{C}$ and the results are given in Table 4.

The Figure 1 showed that penetration values of Sasobit based WMA decreases with increases in rate of additive. The change in penetration values is significant up to the rate of $3 \%$, but the changes in penetration rates decreases as contribution rates are 4 and 5\% compared to the WMA prepared with the rate of $3 \%$ Sasobit. Contrary to the penetration values, there are significant decrease in softening point with increasing in the rate of Sasobit used in the bitumen modification. On the other hand, the figure indicates that decrease about $15^{\circ} \mathrm{C}$ occur while the rate of Sasobit is 5\% in produced WMA. Rotational viscometer based testing gives important data about the effect of Sasobit addition on viscoelastic characteristics of bitumen. There are considerable decrease in viscosity of bitumen samples with Sasobit modification. The changes are seen clearly at lower temperature than the ones at higher temperature.

TABLE 4

MIXING AND COMPACTION TEMPERATURE OF BITUMEN SAMPLES

\begin{tabular}{ccc}
\hline \hline Code & $\begin{array}{c}\text { Mixing Temperature } \\
\left({ }^{\circ} \mathrm{C}\right)\end{array}$ & $\begin{array}{c}\text { Compaction Temperature } \\
\left({ }^{\circ} \mathrm{C}\right)\end{array}$ \\
\hline BB & $164.1-161.0$ & $156.2-151.5$ \\
SAS-0.01 & $161.3-157.2$ & $151.0-144.8$ \\
SAS-0.02 & $160.0-155.4$ & $148.5-141.5$ \\
SAS-0.03 & $159.5-154.6$ & $147.3-139.9$ \\
SAS-0.04 & $157.9-152.6$ & $144.8-137.0$ \\
SAS-0.05 & $156.4-150.7$ & $142.2-133.6$ \\
\hline \hline
\end{tabular}


Table 4 indicated that the mixing and compaction temperatures of base bitumen is higher than that of WMA produced with Sasobit additive. The difference between mixing temperatures determine for BB and SAS- 0.05 occurs about 15 ${ }^{\circ} \mathrm{C}$, while about $12{ }^{\circ} \mathrm{C}$ is determined for differences between compaction temperatures. The results also highlighted that considerable amount of energy conservation can be provided, and preservation of environment can be satisfied due to decrease in greenhouse gas production with WMA.
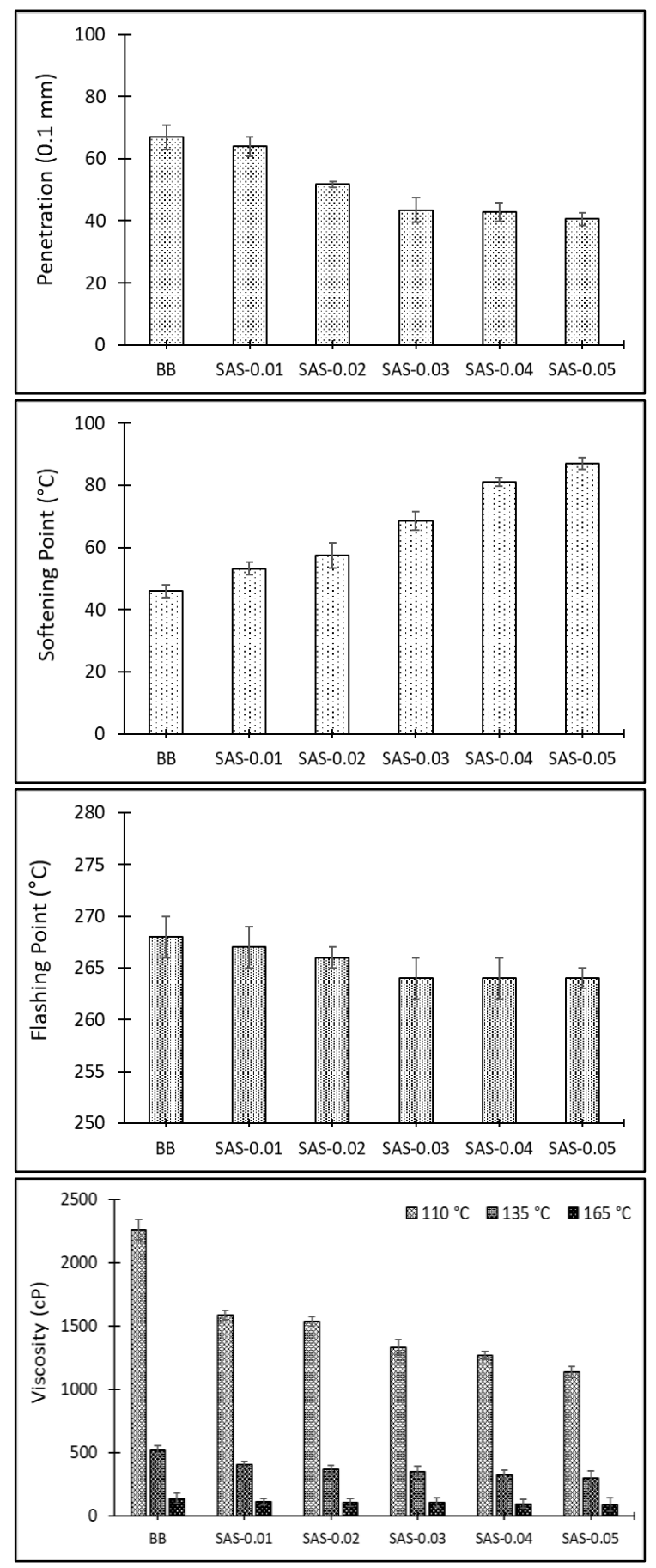

Figure 1. The results of conventional tests

Bitumen is viscoelastic construction material, and it is susceptible to temperature. It is possible to determine the temperature susceptibility characteristic of bitumen with numerous analyses. As mentioned before that the most common two methods are PI and PVN, which are utilized within the scope of the current study. The PI is establishes on penetration and softening point test results, while PVN is constructed on penetration and viscosity test results. The results are presented in Figure 2 for the both cases.

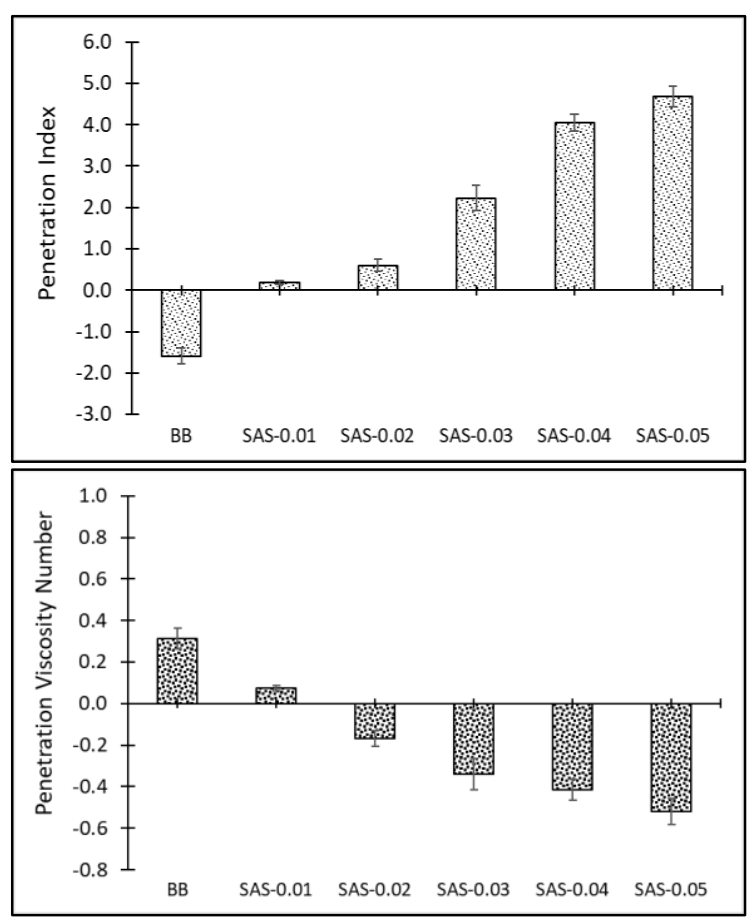

Figure 2. Thermal susceptibility of bitumen samples

The penetration index (PI) indicates temperature susceptibility of bitumen. An increase in the PI means that the bitumen is less sensitive to heat. Contrary to PI, bitumen with higher PVN shows less susceptible temperature property. For a conventional bituminous binder, the expectation for penetration index value are laid between -2 and +2 . When the penetration index results given in Figure 2 are evaluated, it is seen that the penetration index value increases with the addition of Sasobit additive to the bitumen. Therefore, Sasobit additive makes the bitumen resistant against temperature changes. When the analysis of the PVN values given in Figure 2 that calculated based on the results of the penetration tests and the viscosity measured at $135{ }^{\circ} \mathrm{C}$, is examined, it will be seen that it confirms the results obtained in the penetration index analysis.

\subsection{Rheological test results}

Because of the modification of PG 70-22 pure bitumen used in this study to be modified with the Sasobit additive at different rates, it has been observed that the traditional (basic) engineering properties have changed. It is obvious that the rheological properties of bitumen will change with the changing basic engineering properties. For this reason, the scope of the study was expanded by determining the rutting resistance of pure and modified bitumen based on the Superpave classification system with dynamic shear rheometer, which is one of the rheological test methods, as well as determining the classification high failure temperatures. In this context, numerous experiments with DSR were performed on each unaged sample and the short-term aged samples, the results of the test are given in Figure 3 and Figure 4, respectively. 

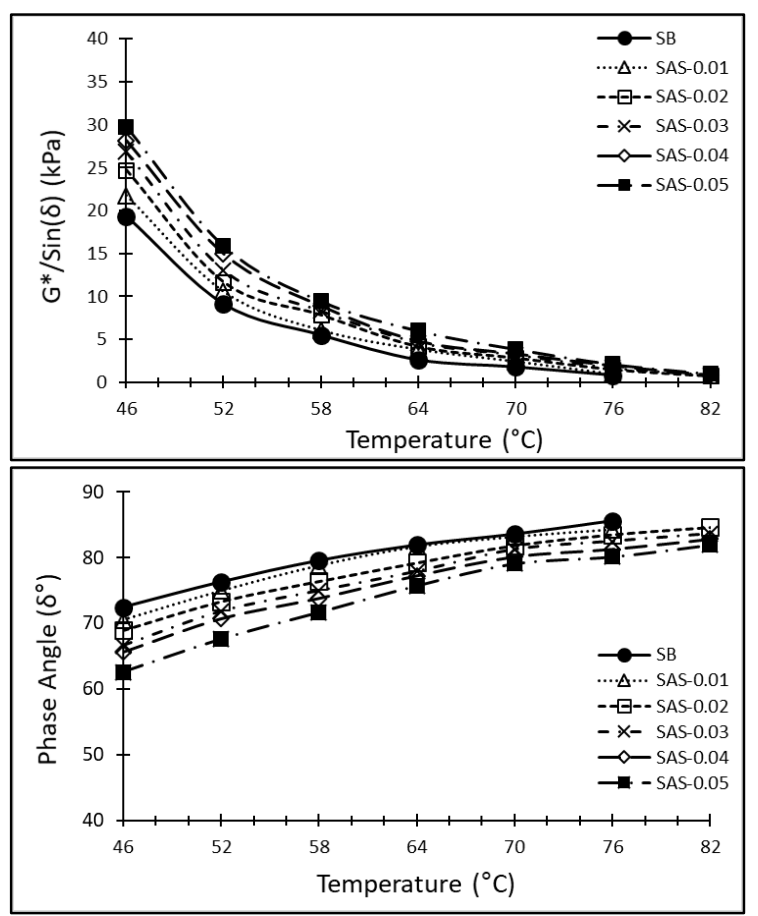

Figure 3. DSR test results of unaged samples

As can be seen in Figure 3, Sasobit additive increases the resistance of the bitumen binder against rutting. In addition, as the temperature increases, it is seen that the measured values, especially the test results obtained at 76 and $82^{\circ} \mathrm{C}$, converge to each other.
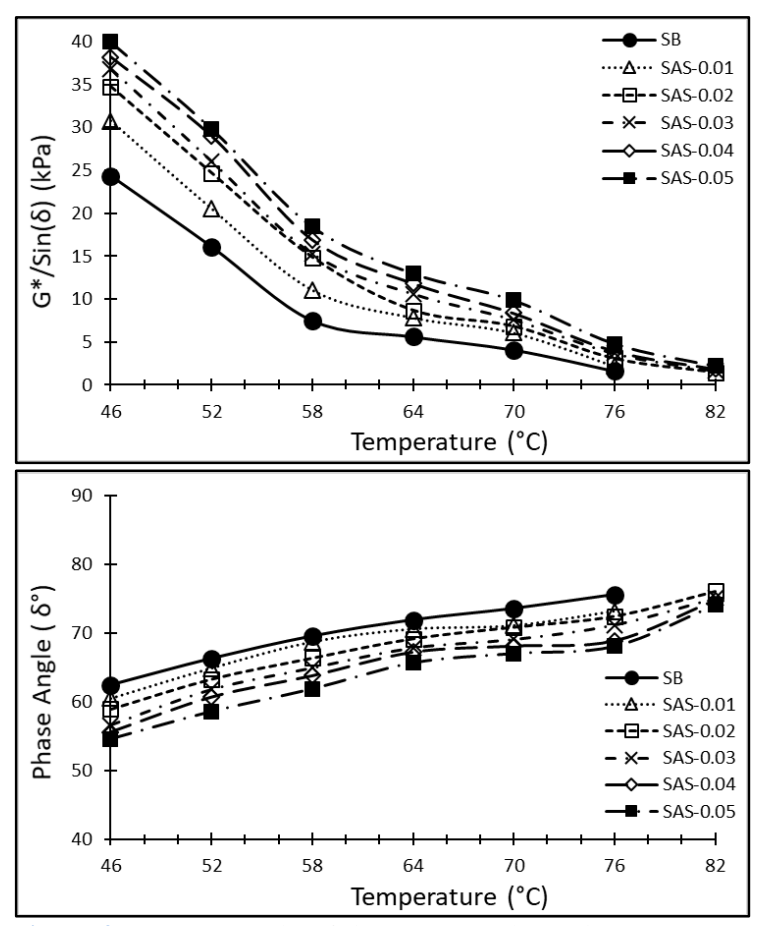

Figure 4. DSR test results of short-term aged samples

Test results on short-term aged specimens (Figure 4) confirm the test results of unaged specimens. On the other hand, the complex modulus values increased due to aging, and the phase angle values decreased due to its more elastic structure.
The failure and classification base temperatures and $\mathrm{G}^{*} / \mathrm{Sin}$ $\left({ }^{\circ} \delta\right)$ for each unaged bitumen sample according to the Superpave system are as shown in Table 5. Likewise, the results of the shortterm aged bitumen samples are given in Table 6 .

TABLE 5

FAILURE AND CLASSIFICATION TEMPERATURES AND COMPLEX MODULUS VALUES OF UNAGED BITUMEN

\begin{tabular}{ccccc}
\hline $\begin{array}{c}\text { Bitumen } \\
\text { type }\end{array}$ & $\begin{array}{c}\text { Failure } \\
\left({ }^{\circ} \mathrm{C}\right)\end{array}$ & $\begin{array}{c}\mathrm{G}^{*} / \operatorname{Sin}\left({ }^{\circ} \delta\right) \\
(\mathrm{kPa})\end{array}$ & $\begin{array}{c}\text { Class } \\
\left({ }^{\circ} \mathrm{C}\right)\end{array}$ & $\begin{array}{c}\mathrm{G}^{*} / \operatorname{Sin}\left({ }^{\circ} \delta\right) \\
(\mathrm{kPa})\end{array}$ \\
\hline BB & 76 & 0,81 & 70 & 1,77 \\
SAS-0.01 & 76 & 0,95 & 70 & 2,43 \\
SAS-0.02 & 82 & 0,72 & 76 & 1,48 \\
SAS-0.03 & 82 & 0,81 & 76 & 1,65 \\
SAS-0.04 & 82 & 0,87 & 76 & 1,96 \\
SAS-0.05 & 82 & 0,98 & 76 & 2,09 \\
\hline \hline
\end{tabular}

TABLE 6

FAILURE AND CLASSIFICATION TEMPERATURES AND COMPLEX MODULUS

\begin{tabular}{ccccc}
\hline $\begin{array}{c}\text { Bitumen } \\
\text { type }\end{array}$ & $\begin{array}{c}\text { Failure } \\
\left({ }^{\circ} \mathrm{C}\right)\end{array}$ & $\begin{array}{c}\mathrm{G}^{*} / \operatorname{Sin}\left({ }^{\circ} \delta\right) \\
(\mathrm{kPa})\end{array}$ & $\begin{array}{c}\text { Class } \\
\left({ }^{\circ} \mathrm{C}\right)\end{array}$ & $\begin{array}{c}\mathrm{G}^{*} / \operatorname{Sin}\left({ }^{\circ} \delta\right) \\
(\mathrm{kPa})\end{array}$ \\
\hline BB & 76 & 1,61 & 70 & 4,07 \\
SAS-0.01 & 76 & 2,21 & 70 & 6,07 \\
SAS-0.02 & 82 & 1,42 & 76 & 3,03 \\
SAS-0.03 & 82 & 1,61 & 76 & 3,65 \\
SAS-0.04 & 82 & 1,87 & 76 & 3,96 \\
SAS-0.05 & 82 & 2,18 & 76 & 4,79 \\
\hline \hline
\end{tabular}

When Tables 5 and 6 are examined, following can be said. The classification temperatures of base bitumen and bitumen modified with $1 \%$ Sasobit additive are the same in case of failure. The complex modulus values of both samples are different from each other. Both the failure and classification temperatures of the bitumen modified with $2 \%$ or more Sasobit additive were found to be higher. This showed that the Sasobit additive increases the resistance of the bitumen to rutting.

\subsection{Economic and environmental effect evaluation}

As can be considered from the current study and present literature that benefits such as significant energy and therefore environmental protection on basis of reduction in greenhouse gases can be provided with using WMA techniques in production of HMA. Since reduction in viscosity increases workability of bitumen, therefore asphalt mixture can be mixed at lower temperatures changing from $100^{\circ} \mathrm{C}-140^{\circ} \mathrm{C}$ dependign on the additive and bitumen type in rate and/or in origin compared to conventional HMA production done at $150^{\circ} \mathrm{C}-190$ ${ }^{\circ} \mathrm{C}$ without sacrificing quality of it $[54,55]$. Since, it has been proven that using WMA technology can reduce energy consumption during production of HMA up to $30 \%$ and gas emissions up to $30-50 \%$, thanks to its ability to be produced at low temperatures [56].

\section{CONCLUSION}

Within the scope of this study, the changes in the modified bitumen obtained as a result of the addition of Sasobit, one of the warm mix asphalt additives, to the bitumen at rates between $1 \%$ and $5 \%$ determined with an increase of $1 \%$ were investigated. In the research, traditional bitumen test methods such as penetration, softening point, flash point, viscosity tests at different temperatures were used. the Mixing and compression temperatures were determined with using the viscosity test results of the bitumen. In addition, analyzes were 
made with two different methods (penetration index, penetration-viscosity number), which are widely used for the evaluation of sensitivity to temperature. Finally, the dynamic shear rheometer test, which is one of the rheological test methods and used to determine the rutting and fatigue resistance of the bitumen binder, was also performed on unaged and short-term aged samples. The results obtained as a result of this study can be listed as follows. Sasobit modification

1. reduced the penetration value of bitumen,

2. increased the softening point value,

3. decreased the flash point value, but this decrease is negligible,

4. reduced the viscosity value, significantly, therefore, decreased mixing and compression temperatures by around $10-15^{\circ} \mathrm{C}$,

5. decreased bitumen thermal sensitivity,

6. increased the resistance against rutting, and

7. changed the class of bitumen according to the Superpave classification system.

The following topics, which are out of the scope of this study but there is a need to be investigated, are suggested to researchers.

- The performance of WMA added bitumen after long-term aging;

- Low temperature performance of WMA added bitumen;

- Properties of modified bitumen produced with different WMA additives;

- Analysis of modified bitumen under the microscope;

- Storage Stability between WMA and bitumen,

- Structural and functional performance of hot mix asphalt using modified bitumen with WMA additives.

\section{ACKNOWLEDGEMENT}

I would like to thank Adana Bitumen Chief of the General Directorate of Highways for supplying bitumen samples and providing laboratory facilities, and TEKNOMET Mühendislik Tem. ve Tic.t Ltd. Şti for providing Sasobit additive.

\section{REFERENCES}

[1] D. Lesueur, "The colloidal structure of bitumen: Consequences on the rheology and on the mechanisms of bitumen modification," Advances in colloid and interface science, vol. 145, pp. 42-82, 2009.

[2] H. Shi, T. Xu, P. Zhou, and R. Jiang, "Combustion properties of saturates, aromatics, resins, and asphaltenes in asphalt binder," Construction and Building Materials, vol. 136, pp. 515-523, 2017/04/01/ 2017.

[3] S. H. Firoozifar, S. Foroutan, and S. Foroutan, "The effect of asphaltene on thermal properties of bitumen," Chemical Engineering Research and Design, vol. 89, pp. 2044-2048, 2011.

[4] J. Neves, A. Correia Diogo, and L. de Picado Santos, "Bituminous Binders and Mixtures," in Materials for Construction and Civil Engineering: Science, Processing, and Design, M. C. Gonçalves and F. Margarido, Eds., ed Cham: Springer International Publishing, 2015, pp. 237-271.

[5] M. Yılmaz, B. V. Kök, N. Kuloğlu, and T. Alataş, "Elastomer türü polimerler ile modifiye edilmiş bitümlü bağlayıcıların depolama stabilitelerinin ve reolojik özeliklerinin," Dokuz Eylül Üniversitesi Mühendislik Fakültesi Mühendislik Bilimleri Dergisi,, vol. 15, pp. 67-77, 2013.

[6] L. Lewandowski, "Polymer modification of paving asphalt binders," Rubber Chemistry and Technology, vol. 67, pp. 447-480, 1994.
[7] C. Giavarini, "Polymer-modified bitumen," Developments in Petroleum Science, vol. 40, pp. 381-400, 1994.

[8] Y. Yildirim, "Polymer modified asphalt binders," Construction and Building Materials, vol. 21, pp. 66-72, 2007.

[9] J. Oner, B. Sengoz, S. F. Rija, and A. Topal, "Investigation of the rheological properties of elastomeric polymer-modified bitumen using warm-mix asphalt additives," Road Materials and Pavement Design, vol. 18, pp. 1049-1066, 2017.

[10] C. Plug, A. de Bondt, and H. Roos, "Performance of bitumen 70/100 obtained from different suppliers," presented at the 5th European Asphalt Technology Association Conference, Germany, 2013.

[11] A. Sağlık and E. Öztürk, "Türkiye'de üretilen sathi kaplamalarda kullanılan bitümlerin performans sinıflarının belirlenmesi " Gazi Üniversitesi Mühendislik-Mimarlı Fakültesi Dergisi, vol. 29, 2014.

[12] U. Isacsson and H. Zeng, "Relationships between bitumen chemistry and low temperature behaviour of asphalt," Construction and Building Materials, vol. 11, pp. 83-91, 1997.

[13] ASMÜD. (2017, 14.08.2017). Karayolu ağının kaplama tipine göre oranı.

[14] M. Yılmaz and B. V. Kök, "Stiren-Butadien-Stiren modifiyeli bitümlü bağlayıcıların superpave sistemine göre yüksek sıcaklık performans seviyesinin ve işlenebilirliğinin belirlenmesi," 2008.

[15] M. Sienkiewicz, K. Borzędowska-Labuda, A. Wojtkiewicz, and H. Janik, "Development of methods improving storage stability of bitumen modified with ground tire rubber: A review," Fuel Processing Technology, vol. 159, pp. 272-279, 2017.

[16] L. Liu, F. Xiao, H. Zhang, and S. Amirkhanian, "Rheological characteristics of alternative modified binders," Construction and Building Materials, vol. 144, pp. 442-450, 2017

[17] I. Gökalp, H. M. Çetin, Y. Özinal, H. Gündoğan, and V. E. Uz, "Polimer Modifiye Bitüm Modifikasyonuna Etki Eden Parametreler Üzerine Bir Literatür Araştırması," Ömer Halisdemir Üniversitesi Mühendislik Bilimleri Dergisi, vol. 8, pp. 954-964, 2018.

[18] J. C. Munera and E. A. Ossa, "Polymer modified bitumen: Optimization and selection," Materials \& Design (1980-2015), vol. 62, pp. 91-97, 2014.

[19] T. McNally, "1 - Introduction to polymer modified bitumen (PmB)," in Polymer Modified Bitumen, ed: Woodhead Publishing, 2011, pp. 1-21.

[20] F. Navarro, P. Partal, F. Martınez-Boza, and C. Gallegos, "Thermorheological behaviour and storage stability of ground tire rubbermodified bitumens," Fuel, vol. 83, pp. 2041-2049, 2004.

[21] R. Blanco, R. Rodríguez, M. García-Garduño, and V. Castaño, "Rheological properties of styrene-butadiene copolymer-reinforced asphalt," Journal of Applied Polymer Science, vol. 61, pp. 1493-1501, 1996.

[22] M. Iwanski and G. Mazurek, "Rheological characteristics of synthetic wax-modified asphalt binders," Polimery, vol. 57, pp. 661-664, 2012.

[23] G. Polacco, S. Filippi, M. Paci, F. Giuliani, and F. Merusi, "Structural and rheological characterization of wax modified bitumens," Fuel, vol. 95, pp. 407-416, 2012

[24] T. Yi-qiu, Z. Lei, G. Wei-qiang, and G. Meng, "Investigation of the effects of wax additive on the properties of asphalt binder," Construction and Building Materials, vol. 36, pp. 578-584, 2012

[25] ISFALT, Asfalt ve Uygulamalart, 1 ed. İstanbul: İSFALT, 2001

[26] EAPA, "Ilık Karışım Asfalt," ASMÜD, Ankara, Türkiye, 2016

[27] T. Litman and D. Burwell, "Issues in sustainable transportation," International Journal of Global Environmental Issues, vol. 6, pp. 331347, 2006.

[28] L. Steg and R. Gifford, "Sustainable transportation and quality of life," Journal of transport geography, vol. 13, pp. 59-69, 2005.

[29] C. Mihyeon Jeon and A. Amekudzi, "Addressing sustainability in transportation systems: definitions, indicators, and metrics," Journal of infrastructure systems, vol. 11, pp. 31-50, 2005

[30] I. Thanaya, S. Zoorob, and J. Forth, "A laboratory study on cold-mix, cold-lay emulsion mixtures," in Proceedings of the Institution of Civil Engineers: Transport, 2009, pp. 47-55, 2009

[31] R. Pereira, A. Almeida-Costa, C. Duarte, and A. Benta, "Warm mix asphalt: Chemical additives' effects on bitumen properties and limestone aggregates mixture compactibility," International Journal of Pavement Research and Technology, vol. 11, pp. 285-299, 2018.

[32] . A. Dokandari, J. Oner, A. Topal, and B. Sengoz, "A Laboratory Study of An Organic Warm Mix Asphalt Additive on Aging Characteristics of Bituminous Mixtures," Pamukkale University Journal of Engineering Sciences, vol. 20, pp. 332-337, 2014.

[33] M. C. Rubio, G. Martínez, L. Baena, and F. Moreno, "Warm mix asphalt: an overview," Journal of Cleaner Production, vol. 24, pp. 76-84, 2012. 
[34] A. K. Arshad, F. A. M. Kridan, and M. Y. A. Rahman, "The effects of Sasobit ${ }^{\circledR}$ modifier on binder at high and intermediate temperatures," International Journal of Engineering and Advanced Technology (IJEAT), vol. 2, pp. 81-84, 2013.

[35] H. Fazaeli, H. Behbahani, A. A. Amini, J. Rahmani, and G. Yadollahi, "High and low temperature properties of FT-paraffin-modified bitumen," Advances in Materials Science and Engineering, vol. 2012, 2012.

[36] S. A. Yero and M. R. Hainin, "Viscosity characteristics of modified bitumen," ARPN Journal of Science and Technology, vol. 2, pp. 500-503, 2012.

[37] D. Cao and J. Ji, "Evaluation of the Long-term Properties of Sasobit Modified Asphalt," International Journal of Pavement Research \& Technology, vol. 4, 2011

[38] P. A. Dokandari and A. Topal, "Effects of warm mix asphalt additives on aging characteristics of bituminous mixtures," Periodica Polytechnica Civil Engineering, vol. 59, pp. 475-486, 2015

[39] X. Liu, A. Sha, C. Li, Z. Zhang and H. Li, "Influence of water on warmmodified asphalt: Views from adhesion, morphology and chemical characteristics," Construction and Building Materials, 264, 120159, 2020.

[40] M. Yue, J. Yue, R. Wang and Y. Xiong, "Evaluating the fatigue characteristics and healing potential of asphalt binder modified with Sasobit $\AA$ and polymers using linear amplitude sweep test,". Construction and Building Materials, 289, 123054, 2021.

[41] F. S. Bhat and M. S. Mir, "Investigating the Performance of NanoModified Asphalt Binders Incorporated with Warm Mix Additives," Journal of Materials in Civil Engineering, 33(11), 04021319, 2021.

[42] S. Carlina, B. S. Subagio, and A. Kusumawati, "The Performance of Warm Mix for the Asphalt Concrete-Wearing Course (AC-WC) Using the Asphalt Pen 60/70 and the Sasobit ${ }^{\circledR}$ Additives," Journal of Civil Engineering, vol. 26, pp. 11-16, 2019.

[43] J. Raveesh, R. Dhumagond, and S. Bijjur, "Experimental Study of WMA by Using Sasobit Additive," International Journal of Applied Engineering Research, vol. 13, pp. 163-165, 2018

[44] J. Zhang, F. Yang, J. Pei, S. Xu, and F. An, "Viscosity-temperature characteristics of warm mix asphalt binder with Sasobit ${ }^{\circledR}, "$ Construction and Building Materials, vol. 78, pp. 34-39, 2015.

[45] G.-j. Zhao and P. Guo, "Workability of Sasobit warm mixture asphalt," Energy Procedia, vol. 16, pp. 1230-1236, 2012.

[46] G. C. Hurley and B. D. Prowell, "Evaluation of Sasobit for use in warm mix asphalt," NCAT report, vol. 5, pp. 1-27, 2005.

[47] CEN, "Bitüm ve bitümlü bağlayıcılar-Ĭğne batma derinliği tayini (Bitumen and bituminous binders - Determination of needle penetration), TS EN 1426," ed, 2015.

[48] CEN, "Bitüm ve bitümlü bağlayıcılar-Yumuşama noktası tayini-Halka ve bilye yöntemi (Bitumen and bituminous binders - Determination of the softening point - Ring and Ball method), TS EN 1427," ed, 2015

[49] CEN, "Petrol ürünleri-Parlama ve yanma noktası tayini-Cleveland açık kap metodu (Determination of flash and fire points - Cleveland open cup method), TS EN ISO 2592," ed, 2006.

[50] ASTM, "Standard Test Method for Viscosity Determination of Asphalt at Elevated Temperatures Using a Rotational Viscometer, ASTM D4402," ed, 2015.

[51] Y. Taşdemir, "Bitümlü kaplamaların termal davranışlarının performans testleri ile incelenmesi," Doktora PhD, İnşaat Mühendisliği, İstanbul Teknik Üniversitesi, 2003

[52] CEN, "Bitümler ve bitümlü bağlayıcılar - Karmaşık kesme modülü ve faz açısının tayini - Dinamik kesme rheometresi (Bitumen and bituminous binders - Determination of complex shear modulus and phase angle Dynamic Shear Rheometer (DSR), TS EN 14770," ed, 2012.

[53] CEN, " Bitüm ve bitümlü bağlayıcılar - Isı ve hava etkisi altında sertleşme direncinin tayini - Bölüm 1: RTFOT yöntemi Başlık (Bitumen and bituminous binders - Determination of the resistance to hardening under influence of heat and air - Part 1: RTFOT method), TS EN 12607-1 " ed, 2015.

[54] K. Karakuzu and H. Özen. "Türkiye Şartlarında Ilık Karışım Asfalt Uygulamasının Ekonomik ve Çevresel Değerlendirmesi," Erzincan Üniversitesi Fen Bilimleri Enstitüsü Dergisi, 13(2), 429-443, 2020.

[55] A. Topal, J. Oner, B. Sengoz, P. A. Dokandari, D. Kaya Evaluation of rutting performance of warm mix asphalt. International Journal of Civil Engineering, 15(4), 705-714, 2017.

[56] Z. Arega, A. Bhasin "Interim Report: Binder Rheology and Performance in Warm Mix Asphalt", Texas Transportation Institute, Texas, USA, Report No. 0-6591, 2012.

\section{BIOGRAPHIES}

İslam GÖKALP obtained his BSc degree in civil engineering from Muğla S1tk1 .Koçman University in 2012. He received MSc. diploma in Civil Engineering from the Graduate School Of Natural and Applied Science of Adana Science and Technology University in 2016 and $\mathrm{PhD}$ degrees in Graduate School Of Natural and Applied Science of Süleyman Demirel University in 2021. His research interests are transportation engineering. . 